\title{
Improving endangered antelope habitat through water quality assessment and collaboration with Kenya Wildlife Service
}

\author{
Tamie Joy Jovanelly (D) \\ Department of Physics, Astronomy, and Geology, Berry College, Mount Berry, Georgia, USA. \\ Corresponding author: Tamie Joy Jovanelly, e-mail: tjovanelly@berry.edu \\ Received: 13-05-2020, Accepted: 30-07-2020, Published online: 08-09-2020
}

doi: www.doi.org/10.14202/IJOH.2020.118-122 How to cite this article: Jovanelly TJ (2020) Improving endangered antelope habitat through water quality assessment and collaboration with Kenya Wildlife Service, Int. J. One Health, $6(2): 118-122$

\begin{abstract}
Background and Aim: A population of endangered sitatunga antelope (Tragelaphus spekii) lives in a free-range environment at Impala Sanctuary in Kisumu, Kenya. Kenya Wildlife Service park officials suspected that increased demands on outdated sewage infrastructure caused animal drinking water sources to become contaminated which resulted in animal sickness and death. In this study, we complete a water quality assessment on open water sources within the park boundaries to determine if water was suitable for animal consumption.
\end{abstract}

Materials and Methods: For the assessment of water, we measure eight physical and chemical parameters ( $\mathrm{pH}$, temperature, fecal coliform, dissolved oxygen, biochemical oxygen demand, nitrates, total phosphates, and turbidity). These eight parameters were chosen because they are used to establish a water quality index (WQI) percentage which proved to be useful to communicate conditions to park rangers, stakeholders, and adjacent landowners.

Results: Through 6 months of assessments, data collection, and analysis, we determined that most open water sources are severely contaminated, ranking on the WQI from $46 \%$ to $58 \%$ (bad to medium). In addition, we compared our data to drinking water standards set by the U.S. Department of Agriculture for livestock to find that only two sites met the minimum criteria. The remaining four sites were exponentially contaminated with levels reaching $10 \times$ recommended values for animal health.

Conclusion: Following these findings, the park was able to attract money for sewage infrastructure rebuilds that resolved the contamination problems. Sickness and death of free-roaming animals, including the antelope, were reduced.

Keywords: animals and contaminated water, Kenya, water quality.

\section{Introduction}

The well-being of animals, humans, and the environment is essential for global health. Just as clean water is a critical nutrient for human populations, holding standards for clean water in confined animal containments or in free-roaming environments should be deemed essential although it remains a topic insufficiently studied [1,2]. Most herbaceous animals, such as antelope or livestock, obtain the greatest proportion of their water requirements from free water intake, instead of water stored in plant matter. A dairy cow, for example, may consume 25 gallons of water each day, although water requirements are influenced by a number of factors including gestation, lactation, activity, environmental temperature, and feed intake [3]. Water intake may decrease if poor quality (low palatability) water is the only option accessible. Decreasing free water intake is undesirable as it can reduce the overall health status of the animal $[4,5]$. It has been described by Natural Resources Conservation

Copyright: Jovanelly. This article is an open access article distributed under the terms of the Creative Commons Attribution 4.0 International License (http://creativecommons.org/licenses/ by/4.0/), which permits unrestricted use, distribution, and reproduction in any medium, provided you give appropriate credit to the original author(s) and the source, provide a link to the Creative Commons license, and indicate if changes were made. The Creative Commons Public Domain Dedication waiver (http:// creativecommons.org/ publicdomain/zero/1.0/) applies to the data made available in this article, unless otherwise stated.
Service [4] and Lewa [6] that poor water quality for grazers (e.g., increases in nitrates, phosphates, and Escherichia coli) can lead to infertility, dehydration, and decreases in milk production. Moreover, it has been shown that doses of any toxicant will have more prominent effects on animals due to the 1 time a day drinking patterns often established by mammal populations [7]. In this paper, we are concerned with the protection and health of the dwindling populations of sitatunga antelope that is indigenous to East Africa; specifically, those of the Lake Victoria watershed.

The last formal census by Kenya Wildlife Service (KWS) of sitatunga antelope occurred in 2013. Then, it was reported that in West Kenya (Kisumu region), a sitatunga antelope was killed each day for bushmeat [8]. More recently, Lewa [6] reported that there may only be 200 sitatunga antelope left in Kenya. These data also indicated that these populations were isolated and, therefore, had little chance of reproduction success without intervention.

Sitatunga antelope is generally marsh dwelling animals that typically prefer habitat in low-lying wet areas. The KWS is particularly distressed about the sitatunga antelope as the lakeshore habitat is under constant threat due to growing population. The city of Kisumu is growing at 3\% per year, whereby $48 \%$ of the urban population lives within the absolute poverty bracket [9]. In addition, flower and rice farming 
have become increasingly detrimental to the marshy wetland environments needed for the success of wild sitatunga antelope [9].

In this study, we completed a water quality assessment on open water sources within the park boundaries to determine if water was suitable for animal consumption.

\section{Materials and Methods}

\section{Ethical approval}

The research team only sampled water did not come into contact with the animals at Impala Sanctuary. The research team collaborated with the Kenya Wildlife Service (KWS) and had approval therein, to access open surface-water sampling sites in the park.

\section{Study area}

The Impala Sanctuary, Kisumu, Kenya $\left(0.0917^{\circ} \mathrm{S}\right.$, $34.7680^{\circ} \mathrm{E}$; Figure-1), was gazetted in 1992 and is home to approximately 15 sitatunga antelopes. The small park $\left(1 \mathrm{~km}^{2}\right)$ is bordered by Lake Victoria on the west, which has become the prime habitat for the antelope that rarely wanders outside the wetland grasses during the daytime hours. Within the park boundaries, the antelope and a variety of other mammals (e.g., Burchell's zebras, impalas, and vervet monkeys) are able to move independently of fencing. Without reign, these animals are allowed to drink from varying, yet limited, open surface-water sources.

\section{Experimental approach}

KWS governs the Impala Sanctuary and initiated this collaboration. KWS Park Rangers and animal caretakers first became concerned about the antelope's health in 2015 when they had been showing signs of drastic weight reduction and three calves born in the park were stillborn. In previous years, challenges with providing clean water supply in the park have been exacerbated by increased building of luxury accommodations and hotels up slope. In addition, there are little environmental regulations or protocols for building which exacerbates the challenges of outdated and overused sewer systems in Kisumu [10].

Although antelope and livestock are not exactly the same physiologically, in our research, we make comparisons of the endangered sitatunga antelope
(Tragelaphus spekii) health to the water quality parameters established for hooved animals as there are not set guidelines for the latter (Table-1). In this study, we complete a water quality assessment on all free intake water sources (i.e., exposed surface-water sources) within the park boundaries of Impala Sanctuary (Figure-1). For the assessment, we measure eight physical and chemical parameters $(\mathrm{pH}$, temperature, fecal coliform, dissolved oxygen (DO), biochemical oxygen demand (BOD), nitrates, total phosphates, and turbidity) using field instrumentation. These parameters have been chosen because they are essential to identifying water suitable for consumption by humans $[2,11,12]$, but are also regarded as important to the overall health of mammals as described by the Agricultural Waste Management Field Handbook [4,13] and U.S. Department of Agriculture for livestock [14]. Furthermore, the parameters can be used to establish a water quality index (WQI) percentage. The WQI is a unit less number ranging from 1 to 100 that reflects the overall health of a system by assigning weighted values to the aforementioned parameters. A higher WQI number is indicative of better water quality (100-90 is deemed excellent water quality, for example). This value allows for contamination to be easily communicated to stakeholders without scientific jargon.

\section{Methods}

Water quality data were collected weekly for a period of 6 months (June-November) at six open air drinking water sights commonly frequented by free-roaming park animals (Figure-1). Samples collected from sites 1,3 , and 4 come from a tributary that flows into Lake Victoria; whereas, sites 2, 5, and 6 are groundwater seeps. Some of the eight water quality parameters $(\mathrm{pH}$, temperature, fecal coliform, DO,

Table-1: Maximum limit for animal ingestion from water (Agricultural Waste Management Field Handbook, 1992).

\begin{tabular}{lc}
\hline Chemical parameter & $\begin{array}{c}\text { Maximum limit for animal } \\
\text { ingestion }\end{array}$ \\
\hline $\mathrm{pH}$ & $6.8-7.5$ \\
Phosphate $(\mathrm{mg} / \mathrm{L})$ & $<1.0$ \\
Nitrates $(\mathrm{mg} / \mathrm{L})$ & $<100$ \\
Turbidity (NTU) & $<30$ \\
Fecal coliform/ $100 \mathrm{~mL}$ & $<1.0$ \\
\hline
\end{tabular}

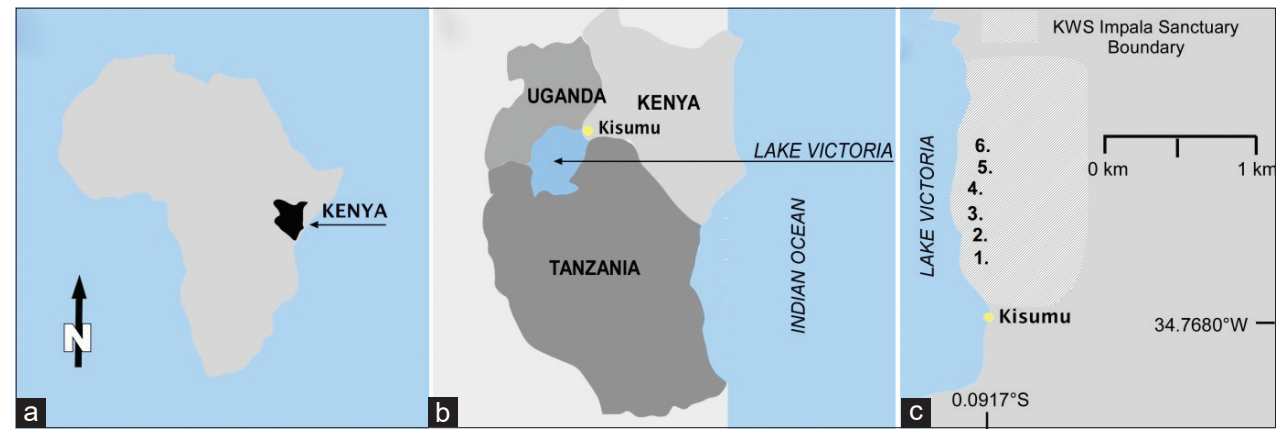

Figure-1: (a) Location map of Kenya in Africa. (b) Location map of Kenya in relationship to Lake Victoria. (c) Site map of the sample sites within the Kenyan Wildlife Service Impala Sanctuary, Kisumu, Kenya. 
BOD, nitrates, total phosphates, and turbidity) were measured on-site using field instrumentation, while others were determined in the laboratory. A handheld Texas Instruments Nspire CX calculator was used with corresponding $\mathrm{DO}, \mathrm{pH}$, and turbidity probes that connected directly to the instrument allowing for immediate field sampling. All probes were calibrated before each field visit using the temperature, humidity, elevation, and air pressure at the field location. The instrument was calibrated for each parameter independently before use according to the instrument guidelines. Nitrates were determined using a zinc reduction method (code 3689-SC) and the phosphorus was established using the vanadomolybdophosphoric acid method (code 3655-SC). Temperature was measured on-site using a mercury thermometer.

At each sample site, water was collected in $250 \mathrm{ml}$ Nalgene amber sample bottles and transported to the laboratory. The fecal coliform test was completed in the laboratory (usually within $4 \mathrm{~h}$ of sample collection) using $3 \mathrm{M}$ Petrifilm Coliform Count Plates by inoculating $1 \mathrm{ml}$ water sample according to the manufacture's guidelines. The plates were incubated at room temperature for $24 \mathrm{~h}$. After $24 \mathrm{~h}$, the colonies on the slide were counted and recorded.

The remaining water samples were capped tightly and placed in a dark cabinet for 5 days and incubated at room temperature. The water sample was tested again after 5 days for DO using the TI-Nspire $\mathrm{CX}$ calculator and probe, and BOD calculated.

\section{Results}

Six sample sites (Figure-1) were chosen at open water sources in Impala Sanctuary that were frequented

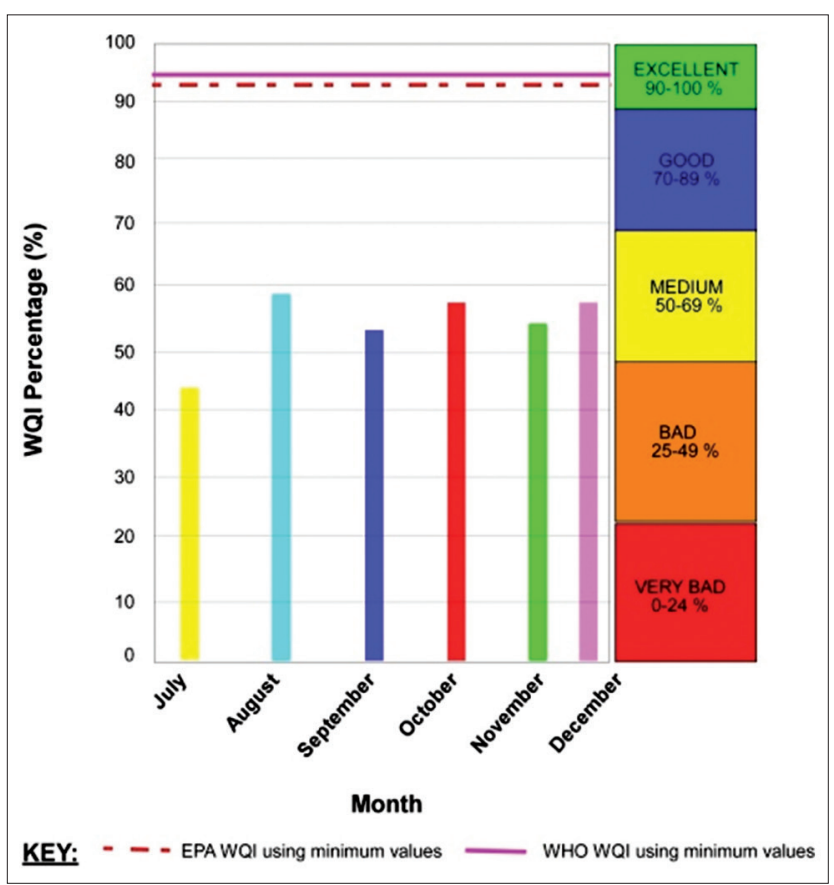

Figure-2: Average monthly water quality indices compared to the United States Environmental Protection Agency water quality index calculated using minimum values for drinking water standards for human consumption. daily by free-roaming animals that included the endangered sitatunga antelope. After 6 months of continual monitoring, a baseline WQI (that represents seasonal variability) was established for each sample site in Impala Sanctuary. We found that the water quality ranked from $46 \%$ to $57 \%$ (bad to medium), however, changes between the dry season (June) to the rainy season (July-November) were found to be negligible (Figure-2). DO ranged between 2.10 and $6.30 \mathrm{mg} / \mathrm{L}$ and was lowest at Site 1 . The water acidity ranged between $\mathrm{pH}$ of 5.98 and 7.74 resulting in WQI values for $\mathrm{pH}$ from below average (54\%). The temperature of the surface water sampled was $26-28^{\circ} \mathrm{C}$. Nitrates were found in all of the samples $(3.0-32.33 \mathrm{mg} / \mathrm{L})$. The lowest nitrates $(3.0 \mathrm{mg} / \mathrm{L})$ of all the sample locations were found at Site 3, a groundwater seep. Phosphates ranged between 2.0 and $47.0 \mathrm{mg} / \mathrm{L}$. July recorded the overall lowest levels of phosphates. Fecal coliform was found at all sampling locations during the duration of the study. These ranged from 6.00 colonies $/ 100$ $\mathrm{mL}$ to those too numerous to count. This as well as the elevated levels of turbidity (9.0-171.5 NTU) greatly impacted the overall WQI values at each of the sampling sites.

\section{Discussion}

The arching goal of this project was to protect and conserve the free-roaming habitat of the endangered sitatunga antelope. As documented by our study, the available drinking water sources record water quality at damaging levels of contamination. After 6 months of continual monitoring, a baseline WQI (that represents seasonal variability) was established for each sample site in Impala Sanctuary. We found that the WQI ranked from $46 \%$ to $57 \%$ (bad to medium). Moreover, only two of the six sample sites met the minimum criteria determined by numerous livestock researchers [15-17] for fecal coliforms, nitrates, phosphates, and turbidity. The remaining four sites were exponentially contaminated with some levels reaching $10 \times$ recommended values for water health.

Through this intensive study, we were able to confidently validate that contamination was coming from upgradient sources including luxury hotels and residential complexes. Our research team agreed that large-scale changes to broken sewage lines, leaking septic tank systems, and waste disposal would take community effort that could be encouraged through a stakeholders meeting that included KWS Park Rangers and Animal Wardens and adjacent (upgradient) businesses. In this meeting, we used the WQI as a tool to communicate the adverse conditions for humans and animals alike. In addition, we discussed environmental regulations enforced by the Natural Environmental Management Authority for wastewater disposal. In promoting this multifaceted grassroots approach to conservation that is community centered, we were able to come to agreement to rebuild infrastructure. With a small amount of external funding, 
we were able to install a French drain along the eastern border of the park boundary. This system rerouted contamination to the subsurface, whereby allowing for microbial activity to break down the pollutants. This reduced surface water overflow issues coming from broken sewer lines (some of which were also fixed). To date, the open water sources have seen a reduction in nitrates, phosphate, fecal coliform, and turbidity to levels acceptable for animal consumption. In addition, the free-roaming animals, including the antelope, appear to be in better health.

Studies have shown that increased environmental knowledge often leads to civic action in environmental/conservation efforts [17-19]. Directly relating to East Africa, this idea of shared scientific evidence could be used to promote the accountability of others, whereby encouraging the implementation of best practices as suggested by the World Bank [20] and Garen [21]. Together, these components support longterm, sustainable benefits to people, animals, and the environment.

\section{Conclusion}

A key component of this project was to train KWS scientists, wardens, and staff on how to use the field instrumentation and to have a thorough understanding of how to interpret results. This was done through a series of workshops, demonstrations, and field experiences. In addition, Jovanelly used a tiered teaching approach, whereby she taught the KWS park scientist who then taught the park warden. The park warden then taught the senior warden. With several people now comfortable with the instrumentation, the park personnel can now troubleshoot problems and have discussions about their results. Undoubtedly, employing the help and support of KWS to conduct long-term WQI monitoring is essential to project success. Through longterm monitoring of the eight parameters at Impala Sanctuary, we will be able to identify improvement or degradation to watershed health based on comparisons to new and old WQI values. In addition, in the future, we hope to sample for heavy metal contamination.

\section{Author's Contributions}

TJJ carried out the research project and subsequently trained the KWS staff. TJJ analyzed the data and wrote the initial draft of the manuscript and revised the manuscript. TJJ read and approved the final manuscript.

\section{Acknowledgments}

The author would like to thank the Rufford Foundation for supporting this project (Grant no. 18715-2). The author would also like to recognize KWS Research Scientist, Stanley Munji and KWS Park Warden and Research Scientist, Christine Boit, for their collaboration and park access.

\section{Competing Interests}

The authors declare that she has no competing interests.

\section{Publisher's Note}

Veterinary World (Publisher of International Journal of One Health) remains neutral with regard to jurisdictional claims in published map and institutional affiliation.

\section{References}

1. Das, A. (2020) Water quality assessment of River Murti for the safety of wildlife, Jalpaiguri, West Bengal, India. Sustain. Water Resour. Manag., 6(2): 1-20.

2. United States Environmental Protection Agency. (2010) National Primary Drinking Water Standards. Code of Federal Regulations Website. Available from: http:// www.water.epa.gov/drink/index.cfm. Retrieved on 02-12-2019.

3. Von Emon, M. (2015) The importance of water quality to livestock production. Farm J., 15(4): 1-12.

4. Natural Resources Conservation Service. (1992) Agricultural Waste Management Field Handbook, National Engineering Handbook. Natural Resources Conservation Service, Washington, DC.

5. Higgens, S.F. and Agouridis, C.T. (2010) Drinking water quality guidelines for cattle. In: Biosystems and Agricultural Engineering. University of Kentucky, Lexington.

6. Lewa, S. (2019) Endangered Rare Antelope Facing Extinction due to Poaching. The Standard Newspaper, Kenya.

7. Raisbeck, M.F., Riker, S.L., Tate, C.M., Jackson, D.R., Smith, M.A., Reddy, K.J. and Zygmunt, J.R. (2008). Water Quality for Wyoming Animal and Wildlife: A Review of the Literature Pertaining to Health Effects of Inorganic Contaminants. University of Wyoming Extensions, Laramie, WY.

8. Mwenja, I. (2003) National rapid survey report on the population status and distribution of Sitatunga in Kenya. Swara, 24(3): 1-21..

9. Kisumu City Council Report. (2016) Fact Sheet. Available from: http://www.citycouncilofkisumu.or.ke. Retrieved on 13-08-2020.

10. Psloft, D.L. and Fulage, C.D. (2008) Water Quality for Livestock Drinking. University of Missouri, Agricultural and Farming Extension, Missouri.

11. Brown, R.M., McClellan, N.I., Deininger, R.A. and Tozer, G. (1970) A water quality index-do we dare? Water Sew. Works, 117(10): 339-343.

12. Mitchell, M.K. and William, S.B. (2000) Field Manual for Water Quality Monitoring. 12 ${ }^{\text {th }}$ ed. Kendal Hunt Publishing, Dubuque, Iowa.

13. Banning, K.L. (2005) Farm Water Quality Considerations. University of New Brunswick, Canada.

14. New Mexico State University. (1995) Water Quality for Livestock and Poultry. Guide M-112. New Mexico State University Extension, Las Cruces, NM.

15. Adams, R.S. and Sharpe, W.E. (1995) Water Intake and Quality for Dairy Cattle. DAS 95. Pennsylvania State Extension, University Park, Pennsylvania.

16. Beede, D.K. (2006) Evaluation of Water Quality and Nutrition for Dairy Cattle. High Plains Dairy Conference, Albuquerque, NM. p24.

17. Jovanelly, T.J., Rodríguez-Montero, L., SánchezGutiérrez, R., Mena-Riveria, L. and Thomas, D. (2020) Under review. Evaluating watershed health in Costa Rican National Parks and protected areas. Sustain. Water Resour. Manag., 6(76): 1-14.

18. Jovanelly, T.J., Johnson-Pynn, J., Okot-Okumu, J., Nyenje, 
R. and Namaganda, E. (2015) Pioneering water quality data on the Lake Victoria watershed: Effects on human health. $J$. Water Health, 13(3): 920-930.

19. Johnson-Pynn, J. and Johnson, L. (2010) Exploring environmental education for East African youth: Do program contexts matter? Child. Youth Environ., 20(1): 123-151.

20. World Bank. (2016) Available from: http://www.data. worldbank.org. Retrieved on 01-02-2020.

21. Garen, E.J. (2000) Appraising Ecotourism in Conserving Biodiversity. Yale University Press, New Haven. p223.

$* * * * * * * *$ 